\title{
Development and Quality Evaluation of Ready to Use Sweet Potato and Mushroom (Pleurotus ostreatus) Tikki mix
}

\section{Virendra Singh* and Lakshmi BK}

Department of Food Process Engineering, Vaugh School of Agricultral Engineering and Technology, Sam Higginbottom Institute of Agriculture, Technology and Sciences, Allahabad, Uttar Pradesh, India

\begin{abstract}
Experiment was conducted at Research Laboratories of Department of Food Process Engineering, SHIATS, Allahabad to utilize the Sweet potato flour and oyster mushroom powder for preparation of Tikki mix. The sweet potato tubers were brought from local market of Allahabad and oyster mushroom obtained from Department of Plant protection, SHIATS Allahabad and then tubers with sorted washed, peeled, sliced, blanched, dried and milled into flour form. Sweet potato flour contains less amount of protein, although rich in dietary fiber content and carbohydrate, so a successful combination with oyster mushroom powder for Tikki mix production would be nutritionally advantageous. In this experiment Sweet potato flour was blended with oyster mushroom powder in ratio of $94 \%, 88 \%, 82 \%$ with control $100 \%$ Sweet potato flour. These were evaluated for sensory analysis that included color, flavor, taste, texture and overall acceptability of SPF and mushroom powder Tikki mix and analyzed for chemical properties viz; moisture, protein, fiber, fat and ash contents. On the basis of nutritional value $T_{2}$ was found high fiber content than other samples and high score for over-all acceptability with containing of $88 \%$ sweet potato flour. Thus, the product was found to be acceptable after the storage period.
\end{abstract}

Keywords: Sweet potatoes flour; Oyster mushroom powder; Standardization; Physic-chemical analysis; Sensory evaluation; Tikki mix

\section{Introduction}

The sweet potato (Ipomoea batatas L.) belong to the Convolvulaceae or morning glory family. Sweet potatoes are good sources of vitamins $\mathrm{C}$ and $\mathrm{E}$ as well as dietary fiber, potassium, and iron, and they are low in fat and cholesterol. Sweet potato, either fresh, grated, cooked and mashed, or made into flour, could, with high potential for success, replace the expensive wheat flour in making buns, chapattis (flat unleavened bread) and mandazis (doughnuts) [1]. Sweet potato flour is used as a raw material for processing into other products.

Mushroom is fleshy, spore-bearing reproductive structures of fungi grown onorganic substrates and for a long time, have played an important role as a human food due to its nutritional and medicinal properties [2]. Mushrooms are a good source of protein, vitamins and minerals and are known to have a broad range of uses both as food and medicine. A high nutritional value of oyster mushrooms has been reported with protein (25-50\%), fat (2-5\%), sugars (17-47\%), mycocellulose (7-38\%) and minerals (potassium, phosphorus, calcium, sodium) of about $8-12 \%$. Edible mushrooms are also rich in vitamins such as niacin, riboflavin, vitamin D, C, B1, B5 and B6.

Sweet potato flour contains less amount of protein, although rich in dietary fiber content and carbohydrate, so a successful combination with oyster mushroom powder for Tikki mix production would be nutritionally advantageous. Shelf life encompasses both safety and quality of food. Safety and spoilagerelated changes in food occur by three modes of action: biological (bacterial/enzymatic), chemical (autoxidation/pigments) and physical. The approach in the present study was to use sweet potato flour in different proportions and important mushroom powder, analyze nutritional attribute and shelf life of Ready to use Sweet potato and mushroom Tikki mix [3].

\section{Materials and Methods}

The experimental studies were carried out in Research Laboratories of Department of Food Process Engineering, SHIATS, Allahabad. The methodology adopted has been described under the below.

\section{Procurement of raw material}

Good quality of sweet potatoes without any bruises and other major ingredients that is fresh oyster mushrooms, spices, corn flour and salt etc were purchased from local market of Allahabad.

\section{Experimental plan}

The experimental plan used for the present research is given in Tables 1 and 2. Figure 1 shows the flow chart for the preparation of sweet potato flour, Figure 2 shows preparation of Mushroom powder flour and Figure 3 shows the flow chart for the preparation of sweet potato and mushroom Tikki mix. Table 2 shows the different combination of sweet potato flour and mushroom powder for tikki mix preparation [4].

Preparation of sweet potato flour: Figure 1 represents Process flow chart for preparation of sweet potato flour

Preparation of Mushroom powder flour: Figure 2 represents Process flow chart for preparation of mushroom powder

Preparation of sweet potato and mushroom Tikki mix: Figure 3 represents Process flow chart for sweet potato and mushroom Tikki mix

\section{Physico-chemical analysis for sweet potato and mushroom Tikki mix}

Moisture content: The moisture content of the developed Tikki mix was determined by the method described AACC (200), Method no-44- 15 A,

*Corresonding author: Virendra Singh, Department of Food Process Engineering Vaugh School of Agricultral Engineering and Technology, Sam Higginbottom Institute of Agriculture, Technology and Sciences, Allahabad, Uttar Pradesh, India,Tel: 0532268 4781; E-mail: virendra.singh788@gmail.com

Received September 11, 2015; Accepted October 06, 2015; Published October 12, 2015

Citation: Singh V, Lakshmi BK (2015) Development and Quality Evaluation of Ready to Use Sweet Potato and Mushroom (Pleurotus ostreatus) Tikki mix. J Food Process Technol 6: 509. doi:10.4172/2157-7110.1000509

Copyright: (c) 2015 Singh V, et al. This is an open-access article distributed under the terms of the Creative Commons Attribution License, which permits unrestricted use, distribution, and reproduction in any medium, provided the original author and source are credited. 
Citation: Singh V, Lakshmi BK (2015) Development and Quality Evaluation of Ready to Use Sweet Potato and Mushroom (Pleurotus ostreatus) Tikki mix. J Food Process Technol 6: 509. doi:10.4172/2157-7110.1000509

\begin{tabular}{|l|l|l|}
\hline S. No. & Parameters & Description \\
\hline 1. & Product & Sweet potato flour and Mushroom Tikki Mix \\
\hline 2. & Variable & Sweet potato flour and mushroom powder \\
\hline 3. & Storage conditions & Ambient \\
\hline 4. & Packaging material & HDPE \\
\hline 5. & Mode of packaging & Sealing Machine \\
\hline 6 & Sample size & $100 \mathrm{~g}$. \\
\hline
\end{tabular}

Table 1: Experimental Plan.

\begin{tabular}{|l|l|l|l|}
\hline Treatments & Sweet potato flour (\%) & Mushroom powder (\%) & Corn flour (\%) \\
\hline $\mathrm{T}_{0}$ & 100.00 & 0.00 & 0.00 \\
\hline $\mathrm{T}_{1}$ & 94.00 & 4.00 & 2.00 \\
\hline $\mathrm{T}_{2}$ & 88.00 & 8.00 & 4.00 \\
\hline $\mathrm{T}_{3}$ & 82.00 & 12.00 & 6.00 \\
\hline
\end{tabular}

Table 2: Treatment Combination.

Selection of sweet potato

$$
\downarrow
$$

Washing and peeling of sweet potatoes
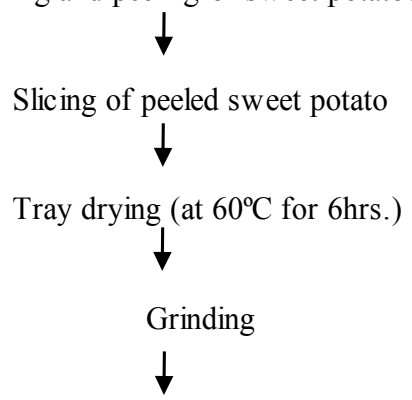

Sieving (70 mesh)

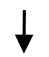

Sweet potato flour

$\downarrow$

Packaging (HDPE)

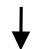

Sealing

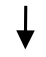

Storage (at ambient temperature)

Figure 1: Process flow chart for preparation of sweet potato flour.

$\%$ Moisture $=\frac{\mathrm{w} 1-\mathrm{w} 2}{\mathrm{w} 1-\mathrm{w}} \times 100$

Where,

$\mathrm{W}=$ weight in gram of the empty moisture dish.

$\mathrm{W} 1=$ weight in gram of the moisture dish with the material before drying.

$\mathrm{W} 2=$ weight in gram of the moisture dish with the material after drying.

Ash content (\%): The residue remaining after the incineration of sample at $550^{\circ} \mathrm{C}-600^{\circ} \mathrm{C}$ is regarded as ash. The ash content was determined by the method described in AACC (2000), Method no. 08-01.
$\%$ Ash $=\frac{\mathrm{W} 2-\mathrm{W} 1}{\text { Wt. of sample }} \times 100$

Where,

$\mathrm{W}=$ weight in gram of the empty dish.

$\mathrm{W} 1=$ weight in gram of the dish with dried material taken for test.

W2 = weight in gram of the dish with the ash.

Protein content (\%): It was determined by the Method no. 32-10.

$\%$ Nitrogen $=\frac{\mathrm{W} 2-\mathrm{W} 1}{\mathrm{~W}} \times \mathrm{N}$ of $\mathrm{NaOH} \times 1.4$

Where

Selection of raw materials

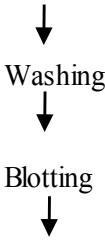

Water blanching $\left(100^{\circ} \mathrm{C}\right.$ for $\left.2 \mathrm{~min}\right)$

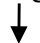

O.T. $(0.5 \%$ citric acid, $0.5 \%$ ascorbic $+10 \%$ Nacl $)$

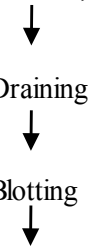

Tray drying $\left(60^{\circ} \mathrm{C}\right.$ for $\left.6 \mathrm{hrs}\right)$

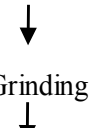

$\downarrow$

Sieving and packaging

Figure 2: Process flow chart for preparation of mushroom powder.

Preparation of composite flour (sweet potato flour, mushroom powder, corn flour)

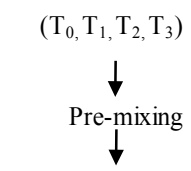

Addition of ingredients

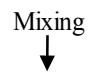

Sweet potato and mushroom Tikki mix

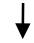

Packaging (HDPE)

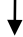

Storage (at ambient temperature)

Figure 3: Process flow chart for sweet potato and mushroom Tikki mix. 
$\mathrm{N}=$ Normality of $\mathrm{NaOH}$

$\mathrm{W}=\mathrm{Wt}$. of sample

$\mathrm{B}=$ Blank titer value $(\mathrm{ml})$

$\mathrm{S}=$ Sample titer value $(\mathrm{ml})$

$\%$ Protein $=\%$ Nitrogen $\mathrm{x}$ Empirical factor

Empirical factor: 5.8

Fiber content (\%): The fiber content was determined by the method described in Ranganna.

$\%$ Fiber content $=\frac{\text { Loss in weight }}{\text { Weight of sample }} \times 100$

Carbohydrate content (\%): It was determined by Duboi's Method.

Absorbance corresponds to $0.1 \mathrm{ml}$ of the test $=\mathrm{x}$ mg of glucose

$100 \mathrm{ml}$ of the sample contains $=0.1 \times 100 \mathrm{mg}$ of glucose $=\%$ of total carbohydrate content.

Fat content (\%): The fat content was determined by the method described in AACC, Method no. 30-25.

$\%$ Fat content $=\frac{\mathrm{M} 2-\mathrm{M} 1}{\mathrm{M}} \times 100$

Where; $M_{1}=$ Initial wt. of round flask

$\mathrm{M}_{2}=$ Final wt of flask + fat

$\mathrm{M}=$ Weight of sample

\section{Sensory analysis of developed tikki mix}

The samples were evaluated on the basis of color, taste, flavor, texture and overall acceptability by a panel of judges using 9-point hedonic scale [5] (Figure 4).

\section{Results and Discussion}

\section{Physico-chemical analysis of developed sweet potato and mushroom tikki mix}

Proximate analysis of sweet potato and mushroom tikki mix is presented in Table 3.

The ash content of sweet potato and mushroom tikki mix was $2.94 \%$ and the moisture content was $8.7 \%$. The carbohydrate content in sweet potatoes was $78.06 \%$. So, it can be analyzed that sweet potato has good nutritional quality [6]. Physical parameters of developed tikki mix (Tables 4 and 5) shows that there was a significant decrease in the diameter of control (T0) and different treatments (T1, T2, T3,) after incorporating tikki mix with Sweet potato flour. Physico-chemical analysis of sweet potato and mushroom tikki mix During the present investigation no significant difference was found in the percent moisture content, and ash content was observed on increasing the incorporation of SPF in the treatments (i.e. T0, T1, T2, and T3) [7]. Whereas, there was a significant change in the values of fiber and fat content. This was because in the present study the formulation was based on 100:00:00\%, 94:04:02\%, 88:08:04\%, 82:12:06\%, of sweet potato flour, mushroom powder and corn flour [8]. Sweet potato flour has a lower moisture content but high carbohydrate and fiber content whereas, corn flour is rich in moisture, protein and carbohydrate content. Therefore, a significant difference was observed between the samples. The moisture content of control and the sample tikki mix was between the range of $1.33 \%$ to $2.86 \%$. But the ash content of control and the sample tikki mix was between the range of $2.41 \%$ to $3.15 \%$. The fiber content was between the range of $2.02 \%$ to $7.36 \%$. Fat content varied from $4.97 \%$ to $6.53 \%$ which was within the acceptable limits for tikki mix. Figure 5 shows the physico-chemical quality of sweet potato and mushroom tikki mix for various treatments (Table 5). The moisture content of tikki mix increased linearly with increase in concentration of sweet potato [9], this is attributed to high water binding capacity of sweet potato which retained higher moisture content in ultimate products. The results for moisture content of the tikki mix were similar with the results obtained by, who incorporated corn flour in preparation of the tikki mix.

The ash content of tikki mix increased significantly due to higher ash content of sweet potato and due to externally added fat during tikki mix preparation. Both refined mushroom powder and sweet potato flour were having lower fat content and hence the total fat content in samples were similar where as there was slight reduction in fat content with increase in sweet potato flour incorporation [10]. The results of proximate composition of sweet potato based tikki mix are similar with the results obtained by the fiber content of tikki mix increased significantly, due to higher fiber content of sweet potato flour. As fiber absorbs large amount of water, it gives a sensation of fullness (having an appetite completely satisfied). Sensory evaluation

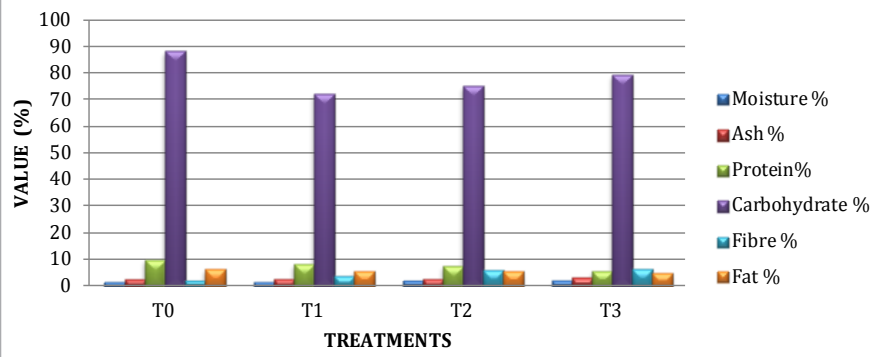

Figure 4: Physico-chemical analysis of standardized sweet potato flour and mushroom tikki mix.

\begin{tabular}{|c|c|c|}
\hline S. No. & Constituents & Percentage (\%) \\
\hline 1. & Ash & $2.94 \pm 0.6$ \\
\hline 2. & Moisture & $8.70 \pm 0.2$ \\
\hline 3. & Protein & $3.15 \pm 0.04$ \\
\hline 4. & Carbohydrate & $78.06 \pm 0.05$ \\
\hline 5. & Fiber & $6.57 \pm 0.03$ \\
\hline 6. & Fat & $0.58 \pm 0.2$ \\
\hline
\end{tabular}

Table 3: Physico-chemical analysis of Sweet Potato Flour and mushroom tikki mix.

\begin{tabular}{|c|c|c|c|c|c|c|}
\hline Treatment & Moisture \% & Ash \% & Protein\% & Carbohydrate \% & Fibre \% & Fat \% \\
\hline $\mathrm{T}_{0}$ & 1.85 & 2.58 & 9.85 & 88.42 & 2.03 & 6.47 \\
\hline $\mathrm{T}_{1}$ & 1.94 & 2.86 & 8.38 & 72.19 & 4.05 & 5.74 \\
\hline $\mathrm{T}_{2}$ & 1.95 & 2.88 & 7.67 & 75.23 & 5.97 & 5.59 \\
\hline $\mathrm{T}_{3}$ & 2.14 & 3.07 & 5.77 & 79.55 & 6.45 & 5.05 \\
\hline
\end{tabular}

Table 4: Physico-chemical analysis of Standardized Sweet Potato Flour and mushroom tikki mix.

\begin{tabular}{|c|c|c|c|c|c|}
\hline Treatments & Color & Taste & Flavor & Texture & O.A.A \\
\hline $\mathrm{T}_{0}$ & 8.66 & 8.66 & 8.00 & 8.66 & 9.00 \\
\hline $\mathrm{T}_{1}$ & 8.00 & 8.00 & 7.33 & 8.33 & 8.00 \\
\hline $\mathrm{T}_{2}$ & 8.33 & 8.66 & 8.33 & 8.66 & 8.66 \\
\hline $\mathrm{T}_{3}$ & 7.66 & 7.33 & 6.66 & 7.33 & 7.33 \\
\hline
\end{tabular}

Table 5: Sensory evaluation for ready to use sweet potato flour and mushroom Tikki mix. 


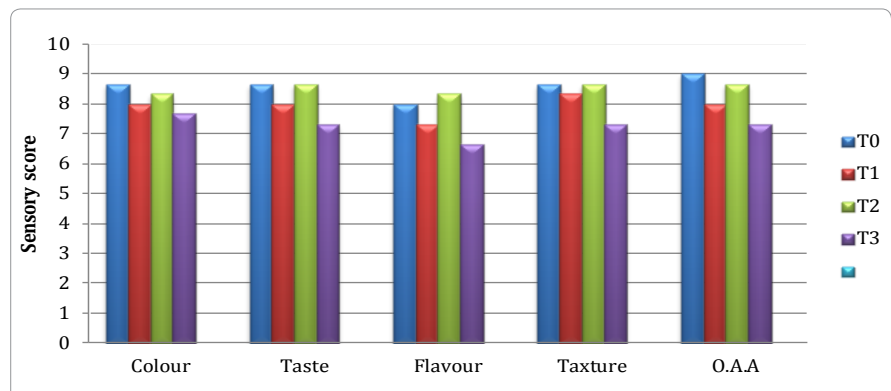

Figure 5: Sensory evaluation of developed tikki mix.

for product standardization tikki mix supplemented by different levels of substitutions of sweet potato flour were sensory evaluated and compared with control tikki mix 100\% sweet potato flour. Data indicated that the percent score of tikki mix containing $82 \%$ sweet potato flour were found to be the most acceptable [11]. At $82 \%$ level of incorporation, all the attributes scored highest level. The color scores of tikki mix with $82 \%$ sweet potato flour reached maximum than to the rest of the proportions similar to the control sample. Thus, incorporation of sweet potato flour at $82 \%$ level improved the sensory attributes namely texture, flavor, color and over all acceptability. The nutritional quality of the developed biscuits was enhanced due to the addition of Sweet potato flour. Thus, the sensory evaluation (Table 5) depicts that highest amount of sweet potato flour that can be incorporated to develop acceptable biscuit was $82 \%$, i.e. sample T2 was the best regarding all sensory attributes [12]. The score of colour reduced significantly to 8.33 , this was due to increasing level of sweet potato flour which gave a color to tikki mix which was not liked much by the panelist. Similarly, the score of taste, flavor and texture also reduced significantly (Tables 3-5).

\section{Conclusion}

It can be concluded that $\mathrm{T}_{2}$ found satisfactory after testing of Chemical analysis and Sensory analysis of developed Sweet potato flour and mushroom Tikki mix were found 2 month of shelf life on ambient temperature with HDPE packaging. There was significant increase in ash, moisture, carbohydrate and fiber content. It is strongly recommended that highly nutritious may be prepared by replacing upto the level of $82 \%$ of sweet potato without adversely affecting the overall acceptability of these snacks. Shelf life analysis was done at an interval of 20 days and the Tikki mix was found acceptable for period of 60 days. This study indicates that feasibility of developing such products.

\section{References}

1. Hagenimana V, Carey EE, Gichuki ST, Oyunga MA, Imungi JK (1998) Carotenoid content after drying and processing sweetpotato products. Ecol Food Nutr 37: 455-473.

2. Benjamin (2007) Rheology and chemistry of dough. In: Pomeranz Y (ed) Wheat chemistry and Technology. (3rd edn), American Association of Cereal Chemists, Minnesota.

3. Ajlouni SD, Beelman RB, Thompson DB, Mou JL (1992) Stipe trimming at harvest increases shelf life of fresh mushroom. J Food Sci 57: 1361-1363.

4. Dove AS, Coote SA (2008) Drying of sweet potato at different temperature. Pol. Journal Food Nutr Sci 57: 487-496.

5. FAO (1972) Food composition tables for use in East Asia. Part- 1, food policy and nutrition division, FAO Rome.

6. Jones (1965) Genetic variation in color of sweet potato flour related to its use in wheat-based composite flour products. Cereal Chemistry 74: 681-686.

7. Peters D, Wheatley C (1997) Small scale agro-enterprises provide opportunities for income generation: Sweet potato flour in East Java, Indonesia. Quarterly Journal of International Agriculture.

8. Suismono (1995) Sweetpotato processing for flour and noodles. Msc thesis, Bogor Agricultural University (IPB), Bogor, Indonesia.

9. Van Hal M (2000) Quality of sweet potato flour during processing and storage Food Rev Int 16: 1-37.

10. Woolfe JA (1992) Sweet potato: An untapped resource. Cambridge, Cambridge University Press, UK.

11. Walde SG, Velu V, Jyothirmayi T, Math RG (2006) Effect of pretreatment drying methods on dehyration of mushroom. Journal of food engineering 74: 108-115.

12. Zhang M, Tang J, Mujumdar AS, Wang S (2006) Trends in micro-wave related drying of fruits and negatives. Trends in food science and technology 17: 524-534. 